\section{Towards Katerina Kolozova, Toward a Radical Metaphysics of Socialism: Marx and Laruelle}

Katerina Kolozova, Toward a Radical Metaphysics of Socialism: Marx and Laruelle (Brooklyn, New York: Punctum Books, 2015)

|Paulo Ricardo Vidal

\section{Bionote}

Paulo Ricardo Vidal (1992) is a Brazilian writer. He holds BA in Law from the University of São Paulo, Brazil (2016), and is graduate in Law from the University Lumière Lyon II, France (2017). He is particularly concerned with the fate of thought after Lacan and Laruelle.

University of São Paulo

paulo.vidal@usp.br

Since the early $1930 \mathrm{~s}^{1}$ the most radical encounter between man and nature qua real exteriority is provided by the collision experience. The colliding enterprise operated by Kolozova in this book, whose modeling should not surprise readers of François Laruelle (whose texts - mainly Introduction au non-marxisme and Philosophie non-standard - obviously constitute obligatory preliminary studies), consists in

\footnotetext{
1 When the first cyclotron was built by John D. Cockcroft and E.T.S. Walton in 1930 at the Cavendish Laboratory at Cambridge, Great Britain. Andrew Robert Steere, $A$ Timeline of Major Particle Accelerators (Master's Thesis, Michigan: Department of Physics and Astronomy, Michigan State University, 2005).
}

\section{Para Katerina Kolozova, Toward a Radical Metaphysics of Socialism: Marx and Laruelle}

Katerina Kolozova, Toward a Radical Metaphysics of Socialism: Marx and Laruelle (Brooklyn, New York: Punctum Books, 2015) |Paulo Ricardo Vidal

\section{Bionote}

Paulo Vidal (1992) é um scriptor brasileiro. Bacharel em Direito pela Universidade de São Paulo, Brasil (2016), e licenciado em Direito pela Universidade Lumière Lyon II, França (2017). Especialmente envolvido com a sorte do pensar pós Lacan e Laruelle.

Universidade de São Paulo

paulo.vidal@usp.br

Desde o ano de $1930^{1}$ o encontro mais radical do homem com a natureza enquanto exterioridade real é providenciado pela experiência da colisão. o empreendimento colisor operado por Kolozova nesta obra, cuja modelização não será estranha para os leitores de François Laruelle (cujos textos - como Introduction au non-marxisme e Philosophie non-standard - constituem leitura prévia obrigatória, obviamente), con-

\footnotetext{
${ }^{1}$ Quando foi construído o primeiro cíclotron por John D. Cockcroft and E.T.S. Walton in 1930 no Laboratório Laboratory em Cambridge, Grã-Bretanha. Andrew Robert Steere, A Timeline of Major Particle Accelerators (Master's Thesis, Michigan: Department of Physics and Astronomy, Michigan State University, 2005).
} 
reinstating the scientificity of Marx's project (contra Marxist philosophical - thus sufficient - readings), approximating it to Laruellian thought dispensed from Philosophie II on, explicitly aiming at recovering its potential for immanent revolutionary political action, which in its turn demands an understanding of the real as outside the range of linguistic intervention, appropriation, and reinvention. This is because it is indispensable, the author warns us, to profess this resisting externality of the real, conceived thus as тро́тос, not oúoi $\alpha,{ }^{2}$ in order to oppose totalitarianism in capitalist speculation, postmodern theory, and (concrete) politics.

To recover the scientificity of Marx's work explicitly and to duly reject the Althusserian coupure $^{3}$ is possible once Kolozova detects

\footnotetext{
2 "Therefore, my use of the Laruellian real is hybridized with what I understand to be the Marxian understanding of the real [...] In Toward the Transcendental Metaphysics of Socialism, I insist on the material or physical determination in the last instance of reality as it seems that it is precisely the physicality and the linguistically incompetent instances of reality that are subject to the capitalist holocaust." Katerina Kolozova, "Reply: Response to Anthony Paul Smith," in Syndicate Symposium on Toward a Radical Metaphysics of Socialism, Syndicate, February 6, 2017, www.syndicate.network/ symposia/philosophy/toward-a-radical-metaphysics-ofsocialism.

3 Agreeing with Michel Henry: "the classical codification of Marx's writing into two stages - that of the 'young Marx' and 'the old Marx' - is a false one. It is an exegetic creation of philosophical interpreters and a close reading of Marx's own text seems to refute this classification. That is why I strove to consistently
}

siste em reencontrar a cientificidade do projeto marxiano (contra as leituras filosóficas marxistas) aproximando-o criticamente do pensamento laruelleano de Philosophie II em diante, com o objetivo explícito de recuperar seu potencial de imanente atuação política revolucionária, para a qual se fará necessária uma compreensão

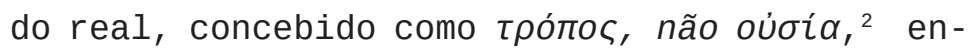
quanto exterioridade fora do alcance da intervenção, apropriação, e reinvenção linguística - pois é indispensável afirmar a exterioridade do real para que se combata a ditadura na especulação capitalista, na teoria pós-moderna e na política (concreta), nos afirma a autora.

Recuperar a cientificidade da obra de Marx ignorando, explícita e justificadamente, a coupure $^{3}$ althusseriana é possível uma vez que

\footnotetext{
2 "Therefore, my use of the Laruellian real is hybridized with what I understand to be the Marxian understanding of the real [...] In Toward the Transcendental Metaphysics of Socialism, I insist on the material or physical determination in the last instance of a reality as it seems that it is precisely the physicality and the linguistically incompetent instances of reality that are subject to the capitalist holocaust." Katerina Kolozova, "Reply: Response to Anthony Paul Smith," in Syndicate Symposium on Toward a Radical Metaphysics of Socialism, Syndicate, February 6, 2017, www.syndicate.network/ symposia/philosophy/toward-a-radical-metaphysics-ofsocialism.

3 Concordando com Henry: "the classical codification of Marx's writing into two stages - that of the 'young Marx' and 'the old Marx' - is a false one. It is an exegetic creation of philosophical interpreters and a close reading of Marx's own text seems to refute this classification. That is why I strove to consistently invoke quotes and bring forth references from both the
} 
its determination-in-the-last-instance in the concept of "labor force," and in its aperture to $\tau u ́ x \eta$, that is to say, in the rupture with the colonizing circularity of philosophical thinking (which Kolozova, admittedly following Laruelle, identifies with capitalism itself qua hegemony of abstraction), which works through the amphibology of thought vis-à-vis the real (as in the privilege example of the classic doubling "Being"/"thought"). In a parallel manner, the scientificity of Laruelle's program is equally affirmed on similar grounds ${ }^{4}$ : the proposal of science de la philosophie (a formula

invoke quotes and bring forth references from both the 'early' and 'the later Marx,' trying to demonstrate that Marx's commitment to certain themes is lifelong and his definition of the communist project has remained essentially unchanged throughout. I claim, and here I concur with Henry, there has never been an 'epistemic break' in Marx. The nervous system of his entire project is essentially non-philosophical or post-philosophical and humanist in a non-humanist sense." Katerina Kolozova, "Reply: Response to Miglena Nikolchina," in Syndicate Symposium on Toward a Radical Metaphysics of Socialism, Syndicate, February 20, 2017, wWw.syndicate.network/ symposia/philosophy/toward-a-radical-metaphysics-ofsocialism.

4 "Non-philosophy and Marxist scientific thought are defined by the same ambitions and admission of the same limitations as those defining science," provided one accepts that "Sciences explain the ways in which realities operate without the pretension to conquer, subjugate, and control the real itself (which is something different from the technological desire to subjugate, control, and exploit)." Katerina Kolozova, "Reply: Response to Dominic Fox," in Syndicate Symposium on Toward a Radical Metaphysics of Socialism, Syndicate, February 13, 2017, WWW.syndicate.network/symposia/ philosophy/toward-a-radical-metaphysics-of-socialism. a autora encontra sua determinação-na-últimainstância no conceito de "força de trabalho," e

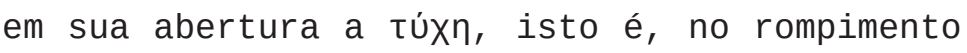
com a circularidade colonizadora do pensamento filosófico (que Kolozova, seguindo explicitamente Laruelle, igualará ao próprio capitalismo qua hegemonia da abstração), que opera pela anfibologia do pensamento vis-à-vis o real (como na clássica duplicação "Ser" e "pensamento", por exemplo). Paralelamente, a cientificidade do projeto de Laruelle é igualmente afirmada com argumentos semelhantes": a proposta de "ciência da filosofia" (que aparece como sinônimo da empresa laruelleana de não-filosofia em determina-

\footnotetext{
'early' and 'the later Marx,' trying to demonstrate that Marx's commitment to certain themes is lifelong and his definition of the communist project has remained essentially unchanged throughout. I claim, and here I concur with Henry, there has never been an 'epistemic break' in Marx. The nervous system of his entire project is essentially non-philosophical or post-philosophical and humanist in a non-humanist sense." Katerina Kolozova, "Reply: Response to Miglena Nikolchina," in Syndicate Symposium on Toward a Radical Metaphysics of Socialism, Syndicate, February 20, 2017, www.syndicate.network/ symposia/philosophy/toward-a-radical-metaphysics-ofsocialism.

4 "Non-philosophy and Marxist scientific thought are defined by the same ambitions and admission of the same limitations as those defining science," provided one accepts that "Sciences explain the ways in which realities operate without the pretension to conquer, subjugate, and control the real itself (which is something different from the technological desire to subjugate, control, and exploit)." Katerina Kolozova, "Reply: Response to Dominic Fox," in Syndicate Symposium on Toward a Radical Metaphysics of Socialism, Syndicate, February 13, 2017, www.syndicate.network/symposia/ philosophy/toward-a-radical-metaphysics-of-socialism.
} 
that appears synonymous to the Laruellian nonphilosophy enterprise in some moments of its evolution) is based on the conception of science as naïve and primitive thought qua search for the apprehension of the real in an exhaustive and systematic fashion while avoiding implicating the duplication of representative thinking crystallized in ideas of "truth" or "essence," or confirming positivist dogmas. For Kolozova, respectively, no science can dictate the apolitical natural laws for its own historical development.

It is opportune for us to deter ourselves around the Marxian concept of Entfremdung, as this idea is the way in which Kolozova leads us to the theory of the German thinker, its point of approach with Laruelle's nonpsychoanalytic positions, and the book's major political motif. Such estrangement in no way refers to an essentially or existentially human praedicamentum, appearing, however, as general result of a series of typically philosophical and capitalist abstractive operations that submit the lived reality to fetishistic logic. overcoming the condition of estrangement, i.e., purging alienation from the real via political combat, makes up the major metaphysical ("muscular" yet properly metaphysical - and Kolozova declares the urgency of rescuing metaphysics ${ }^{5}$ from philosophical imperialism)

${ }^{5}$ Which constitutes an inescapable human horizon. See dos momentos de sua evolução) está calcada na concepção da ciência enquanto pensamento primitivo e naïf como busca pela apreensão do real de maneira exaustiva e sistemática sem que se implique na duplicação do pensamento represent ativo cristalizado nas ideias de "verdade" ou "essência", ou que se confirmem os dogmas positivistas. Para Kolozova igualmente, nenhuma ciência pode decretar leis naturais apolíticas para seu próprio desenvolvimento histórico.

o conceito marxiano de Entfremdung é a entrada que Kolozova nos oferece à teoria do pensador alemão, seu ponto de aproximação com as posições não-psicanalíticas de Laruelle, e o motivo político maior do livro. Detenhamo-nos, portanto, nele. Tal estrangement de modo algum se refere a uma predicação essencial ou existencialmente humana, mas aparece como resultado geral de operações de abstração, tipicamente filosóficas e capitalistas, que submetem a realidade vivida à lógica do fetiche. A superação da condição de estrangement, isto é, a expulsão da alienação do real via luta política, é interpretada como objetivo metafísico ("muscular," mas propriamente metafísico - e Kolozova afirma a urgência de se resgatar a metafísica ${ }^{5}$ do imperialismo filosófico) maior no pensamento marxi-

\footnotetext{
5 Que constitui um horizonte humano inescapável. Leia Katerina Kolozova, "Metaphysics of Finance Economy: of its Radicalization as the Method of Revoking Real Economy," Identities: Journal for Politics, Gender and Culture, Vol. 11, No. 1-2 (2015), 19-31.
} 
objective inside Marxian thought. Estrangement, for Laruelle, in an assertion that adequately expresses the productivity of comparing both writers; it "is experienced or lived [...] as trauma, and is a form of oppression by virtue of the sheer experience of inflicted violence and pain that it causes to the human 'body' and 'spirit.'" (p. 24) Estrangement is logically anticipated in the process of alienation when one assumes the actuality (or, at least, amenity) of the spinozist conatus, as does Kolozova.

The analysis of the process of alienation leads us through considerations regarding commodity as foreclosure of physicality to the vampiric hegemony of the code in the context of contemporary capitalism. Scrutinizing speculative finance industry which, by negating sensual life, implies the inexistence of economy, amounts to the point of departure for the study of austerity measures as applied by Merkel and Obama after 2008. Kolozova then proposes a deconstruction of neoliberal fantasies and myths (exemplified by the "self-perfecting" of the wanna-be capitalist individual subject to continued wage labour-oriented education in the context of painfully exaggerated compulsory job mobility): the logical indetermination of the use-value (in the form of the significance

Katerina Kolozova, "Metaphysics of Finance Economy: of its Radicalization as the Method of Revoking Real Economy," Identities: Journal for Politics, Gender and culture, Vol. 11, No. 1-2 (2015), 19-31. ano. Estrangement, para Laruelle, numa afirmação que expressa adequadamente a produtividade da comparação entre os dois autores, "is experienced or lived [...] as trauma, and is a form of oppression by virtue of the sheer experience of inflicted violence and pain that it causes to the human 'body' and 'spirit." (p. 24). Es trangement é previsto logicamente no processo de alienação em si dada a realidade do conatus spinozista assumida pela autora.

A análise do processo de alienação nos leva através de considerações sobre a commodity enquanto denegação da fisicalidade até a hegemonia vampírica do código no contexto do capitalismo contemporâneo. As finanças e a indústria financeira especulativa, que negando a vida sensual, implicam na própria inexistência de uma economia propriamente dita, são ponto de partida para o estudo das políticas de austeridade implantadas por Merkel e Obama pós-2008; e para a desconstrução de das fantasias (como a do autoaperfeiçoamento do indivíduo wanna-be capitalista sujeito a uma educação continuada orientada ao trabalho assalariado num contexto de exagerada e dolorosa mobilidade empregatícia), e dos mitos neoliberais, como o da indeterminação lógica do valor-de-uso (na forma da significância da "economia bruta", afinal de que outro modo se justificaria a necessidade das medidas de austeridade enquanto medidas de concentração de renda?), e o da posição fragi- 
of "brute economy," behold this absolute foreclosure, how else would austerity measures qua wealth concentration procedures be justifiable or - critically - intelligible), and the weakened position of national states facing transnational banks, being the most eloquent cases, revealing thus economy as immer schon political.

Besides being a critical reader of Baudrillard, from whom she fuels herself in her examinations of finance capitalism's axiomatic abstraction, and a spinoza enthusiast (it is out of Ethics, ultimately, that the author takes the most radical imperatives for political activity), Kolozova passes through the canon of feminist thought, with determination-inthe-last-instance of exploitation as sexual exploitation, as developed by Shulamith Firestone, and the cyborg demands of Haraway. The author further dialogues with accelerationist philosophers such as Nick Land, Alex Williams and Nick Srnicek, partially absorbing them, assembling a work which forces itself as inevasible to anyone interested in the critical and political potential of the surging nonstandard incursion. lizada dos Estados nacionais face aos bancos, com a revelação da economia como immer schon política.

Além de leitora crítica de Baudrillard, de quem se alimenta em suas considerações sobre a abstração axiomática do capitalismo financeiro, e entusiasta de spinoza (é do tratado Ethica, no final das contas, que Kolozova retira os imperativos mais radicais para a atuação política), passa Kolozova pelo cânone do pensamento feminista, com a determinação em última instância da exploração enquanto exploração sexual desenvolvida por shulamith Firestone e as demandas ciborgues de Haraway. Dialoga igualmente a autora macedônia com os filósofos aceleracionistas Nick Land, Alex Williams e Nick Srnicek, absorvendo-os parcialmente. A obra se afirma como incontornável aos interessados no potencial crítico e político da surgente incursão non-standard. 